\title{
Is There a Relationship between Business Strategies and Training Emphasis on Job Categories in Successful Companies in Kenya?
}

\author{
Mbithe Anzaya
}

\begin{abstract}
Introduction
Although modern technology has been used to improve business performance, it has also been realized that competent people are crucial in the implementation and utilization of innovative work systems. Traditionally, technology and information have been the sources of competitive advantage, but the scenario has changed significantly and technology and information alone cannot be relied on as the sole means of gaining a competitive advantage (Tung \& Punnet, 1993). Although modern technology has been used to improve business performance, it has also been realized that competent people are crucial in the implementation and utilization of innovative work systems (Torraco \& Swanson, 1995). Competitive advantage is affected by the globalization challenges such as bigger markets, information flow or exchange, and better products or services. However, businesses can face the challenges by having a better-skilled, well-informed and adaptive or flexible work force through the mechanism of training, thus, the need for the use of strategies to accomplish this. Business organizations are now viewing people as strategic resources (Salaman, 1992).
\end{abstract}

\section{Literature Review}

The study builds on previous research findings and addresses human resource issues that have not been addressed in previous studies. Sugarman (2001) stated that organizations that have the ability to learn faster and better than their competitors are able to meet internal and external challenges, and therefore, succeed because they align the internal operations with external needs. Having people who have the ability to learn faster than their competitors can be realized by organizations, if the organizations invest in people through training. This is because people who have skills, knowledge and abilities are able to learn and implement the strategies required by the organizations so that the organizations can compete effectively.

The gap in knowledge on the relationship between strategy type and HRD in a developing country made it necessary to carry out this study. Previous studies have shown how different strategy types related to organizational structure (Chandler, 1962; Drucker, 1954). Other studies have addressed the Defender, Analyzer, and Prospector strategy types and their relationship to job and task characteristics (Delery, 1993). Relatively little empirical work has been done on the relationship between business strategies (i.e., Defender, Analyzer, and Prospector,) and HRD in developing countries, particularly in Sub-Saharan Africa. The few studies that have been done in Kenya (Gershenberg, 1987; Kamoche, 1992; Nyamberega et al., 2000) have focused on HRM, but relatively few studies have been carried out on HRD. Testing the Miles and Snow (1978) strategy model in Kenya was important because as organizations compete globally, researchers and practitioners will know if the same business strategies used in companies are applicable in the different business environments. 
The literature indicated that business strategies and training are important in organizations and that there was an increased awareness of the relationship between business strategy and training (Brewster \& Pickard, 1994; Larsen, 1994; Latham, 1988). However, Brewster and Pickard (1994) stated that there was a need to support this claim, and Walumbwa (2001) recommended that further research be done to yield additional information about the dynamics of training as a process of organizational success. As human resources, people are increasingly being seen as vital to an organization's competitive advantage.

\section{Theoretical Framework}

The current study is guided by human capital theory. Human capital theory falls under the economic theory which views human capital as a way to add value to organizations (Fitz-enz, 2000). People have the knowledge, skills, and abilities that can be utilized to create economic value for organizations (Loewenstein \& Spletzer, 1999; Miles \& Snow, 1994; Weinberger, 1998; Youndt, Snell, Dean, \& Lepak, 1996).

Several scholars have addressed economic theory and its relationship to business strategy, business units, and HRD (Bowman, 1995; Delany \& Huselid, 1996; Delery, 1993; Fitz-enz, 2000; Jackson, Schuler, \& Rivero, 1989; Kalata, 1999; Weinberger, 1998). According to Becker (1975), "investments in human capital are activities that influence future monetary and psychic income by increasing the resources in people" (p. 9). Within organizations, investments are made to improve the knowledge, skills, and attitudes of people to improve performance. Improved productivity, quality, or services are outcomes of trainee job performance (Fitz-enz, 2000). Investment in human capital is vital for the organizations if they are to have a competitive advantage (Pfeffer, 1994).

Several scholars had utilized human capital theory to study the relationships between business strategy, business units, and HRD. In this view, humans are resources that use their knowledge, skills, and abilities to enable companies to increase improve their performance. Snell and Dean (1992) stated that skills, knowledge, and attitudes represent capital because they enhance productivity. The strategies used in this study were based on Miles and Snow (1978) strategy typology. This strategy typology explains different characteristics for the different strategies. For example, those using the Defender strategy grow by penetrating into their current market, Analyzer growth is through market penetration and product market development, and Prospectors experience growth through new market penetration and development of new products (Miles \& Snow 1978). This study utilized the Miles and Snow (1978) typology, which was operationalized and defined, by looking at what the model said about the different strategies, and then comparing that to what the self-reported Defenders, Analyzers, and Prospectors reported in regard to training and job categories. For example, it has been established that Defender strategy develops the human resource (Miles \& Snow, 1984). Based on the work of Miles and Snow (1978) it means that when companies self-report that they were Defenders, one would expect the companies using the Defender strategy in the Kenyan environment to also state that they build their human resources. This would then confirm that the model was relevant in Kenya. 
The strategy typology also indicates that Analyzers are good at imitation and are "second to market" and they also have some stable products (Miles \& Snow, 1978; 1984). The Analyzer strategy is said to have characteristics of both the Defenders and the Prospectors (Miles \& Snow, 1978; Raghuram \& Arvey, 1994). Analyzers combine the strengths of Defenders and Prospectors (Miles \& Snow 1978). Raghuram and Arvey (1994) noted that Analyzers use formalized structures and processes and, that managers in those organizations watch their competitors closely. It is assumed that this is what helps the Analyzers imitation process, since they are aware of what the competitors are doing and can therefore improve on it at lower costs. Based on this description of the Analyzers, one would expect that they would train human resources that enable them to produce at lower costs than the Prospectors and train human resources who are able to maintain their core products; a characteristic that is seen in the Defenders. One would also expect the training provided by Analyzers to focus on job-specific technical training, which is a training focus of the Prospectors, and on management training, which is a training focus of the Defenders.

The model further explains that Prospectors are "first to market" innovators, they have technological flexibility, and are creators of change to which competitors respond (Miles \& Snow, 1978; Raghuram \& Arvey 1994; Solymossy, 2003). Based on this information, one would expect the Prospectors to be able to adjust to the frequent technological changes by job-specific training so that their human resources can deal with the technology. Since strategy typology states that the Prospectors are innovators and first to market, in asking the question on who is trained, one would expect to find that the prospectors train the people on the shop floor, so that they can maintain quality of output. To explore the expected relationships between the three strategy types and their training emphasis on job categories, the following research question was used to guide this study. What is the relationship between self-reported strategy type and the emphasis on training for various job categories (e.g. line worker, sales people and middle managers)?

\section{Research Method}

This study utilized survey research methods with data being collected using a questionnaire that was administered onsite. The sample for the study consisted of forty-eight companies in Nairobi that had participated in the "Company of the Year Awards" (COYA), since its inception in the year 2000. Data analysis included descriptive statistics, computing correlations analysis of variance.

\section{Population and Sample}

The target population for this study was all business companies that had registered and been selected to participate in COYA since the inception of the awards. COYA is an annual yearly event in Kenya that seeks to "celebrate excellence in management" in nine areas: corporate planning, marketing, human resources, information, quality, finance, creativity and innovation, corporate citizenship, and environment.

The sampling frame for this study was a list of all the companies that had participated in COYA. The list and information about the companies was obtained from the Kenya 
Institute of Management (KIM). Information included the location of the company, the sector (e.g., service or manufacturing company), and whether it was a local or a multinational company.

Using the sampling frame it was established that sixty-one companies had participated in COYA, it was further established that fifty-two of these companies were in the Nairobi area. The initial plan was to use the whole population in Kenya (Mugenda \&Mugenda, 1999). However, upon getting the sampling frame, it was realized that $80 \%$ of the companies that had participated in COYA were based in Nariobi. So all the Nairobi companies were the accessible population, and they were selected as a convenience sample. In addition, the companies in Nairobi were exposed to the same operating environment and, as such, they would be a fair representation of the whole population. The researchers also established that, of these fifty-two companies, three companies had been approached, but had never actually participated in COYA. One company did not meet the selection criteria. That left forty -eight companies in the final sample.

Of the forty-eight companies, thirty-eight companies $(79.2 \%)$ completed the questionnaire. The companies that declined to participate were compared to those that participated in the study and there were no differences between the two groups in terms of number of employees, internally generated annual turnover, legal registration, and duration of operation within Kenya, indicating that non-response bias was not an issue in this study.

\section{Instrumentation}

The study administered a modified survey instrument that had been used in another study in the U.S. (Kalata, 1999). The use of an already designed and tested questionnaire helped in reporting the validity that others had found in previous studies. Validity had been measured using one way analysis of variance based on Duncan's multiple range that examines differences between all combinations of groups (Shortell \& Zajac, 1990). The results provided strong support for the measurement of validity of Miles and Snow's (1978) strategic types (Shortell \& Zajac, 1990; James \& Hatten, 1995). The researcher, therefore, felt confident in using Miles and Snow's (1978) strategic types for the current research.

Permission to use the existing questionnaire was obtained from Kalata (1999). The original questionnaire had questions about general HRD. Two major questions in the original study were developed to gather general information namely: (a) the number of employees served by HRD function and (b) the approximate HRD annual budget.

Business strategy questions in the original questionnaire were adapted from Shortell and Zajac's (1990) instrument measuring business strategy types. The instrument had brief descriptions of each strategy type. Questions on training from the original questionnaire were derived from the review of American Society for Training \& Development, State of Industry Report [ASTD] (1998). Questions were asked about general training and included management-supervisory skills, job-specific technical 
skills, customer service training, team training and awareness training. The author of the questionnaire (Kalata, 1999) stated that these were selected because they were measures used in the Training and Industry Report and the ASTD Report and were seemingly representative of training provided in the United States, Jackson et al. (1989) used the same procedure to measure personnel practices in a U.S. organization.

One question sought to find out if the companies had a specified policy on training. Some new questions were added to the questionnaire, and the modified instrument was pilot tested on two companies within the target population. Some of the new questions added to the original questionnaire focused on the strategy used by the company if it was different from the strategies described in the questionnaire. The respondents were also asked to indicate on a scale of 1 to 5 how closely their company fit into the different strategies. There was an additional question for the CEO to explain the strategy the company endorsed in case the strategy was different from those described in the questionnaire. One of the modified questions requested the CEOs to self-report the strategy that they felt best described their company.

The respondents were also asked to comment on any changes in the amount of money spent on specific training types over the last three years. According to Kalata (1999), the Defender strategy type spends the least amount of dollars per employee, followed by the Analyzer strategy type. The Prospectors spend the most dollars per employee. The prospectors spend the most dollars per employee. Therefore, asking for information on how much is spent on employee training would establish if what others had found held true in the Kenyan context. The information provided by the companies on strategy types and their expenditures helped confirm if the expenditure on the development of employees were related to strategy type.

There was a question on the job categories of those that received the training. This question was included to validate the information provided on training types, because previous research showed that the Defender strategy type focused on line workers, Analyzers focused on middle managers, while Prospectors focused on professionals (Kalata, 1999). Therefore, when business organizations indicated that their training was mainly focused on professionals, the researcher would verify that the same organization self-reported that it used the prospector strategy. However, it was noted that this aspect might vary depending on the business environments within which the companies operate.

The questionnaire was designed to take twenty to twenty-five minutes to complete and it was structured to provide data in percentages (e.g., percentage of annual training time). The questionnaire addressed general questions related to the HR department, then information related specifically to business strategies, and finally information on training among others. The use of an already designed and tested questionnaire helped in reporting the validity that others had found in previous studies. Validity had been measured using one-way analysis of variance. The results provided strong support for the measurement of validity of Miles and Snow's (1978) strategic types (James \& Hatten, 1995; Shortell \& Zajac, 1990). The researcher, therefore, felt confident in using Miles and Snow's (1978) strategic types for the research. Confidentiality was maintained by assigning a numeric code to each questionnaire representing the 
different companies. A numerical code was used during data entry as the only identifier.

\section{Data Collection and Analysis}

The questionnaire was pilot tested on two business organizations that were part of the target population. CEOs and HR managers filled out the questionnaire. After pilot testing, the questionnaire was revised to incorporate the feedback that was provided and to fit the Kenyan context, within which it was administered. For all the companies, the CEOs and HR manager were first contacted to request an hour's appointment for the data collection session. This was to allow for the delivery of the questionnaire and provide enough time for the CEOs and HR managers to get information required to complete the questionnaire.

Data from the questionnaires were analyzed using the Statistical Package for the Social Sciences (SPSS). Data analysis included descriptive statistics and analysis of variance (ANOVA). In addition to the ANOVA, Tukey's Post Hoc analyses test was used to compare group means and identify differences that were significant. Analysis of variance (ANOVA) was used to test for significance between the self-reported strategies and the emphasis on training for various job categories (e.g. line worker, sales people and middle managers).

\section{Results}

The guiding purpose of this study was to establish the relationship between selfreported strategy type and the emphasis on training for the various job categories.

Results of cross-tabulation of actual mean percentage for training allocation by job category by strategy are, presented in Table 1 , showed that Defenders place emphasis on training sales people $(19.50 \%)$, professionals $(19.00 \%)$, and first line supervisors and middle managers $(18.08 \%)$. Analyzers place emphasis on training professionals $(41.00 \%)$, line workers $(17.50 \%)$, and middle managers $(16.25 \%)$. Prospectors allocated the largest percentage of training to line workers $(31.31 \%)$, followed by sales people $(15.77 \%)$, and then professionals $(13.53 \%)$.

Analysis of variance was carried out to determine if there were significant differences between strategies in percentage of training for job categories. The results are presented in Table 2. Based on ANOVA results, job category and the interaction between strategy and job category were significant. Job category was significant at $\mathrm{p}=0.000$ and the interaction for strategy and job category was significant at $p=0.000$. These results clearly showed that within specific strategies there was discrimination of training allocation for the job categories (see Figure 1) 
Is There a Relationship between Business Strategies and Training...

Table 1

Actual Mean Percentage for Training Allocation on Job Category by Strategy

\begin{tabular}{|l|l|l|l|l|l|l|l|}
\hline $\begin{array}{l}\text { Strategy } \\
\text { Type }\end{array}$ & $\begin{array}{l}\text { Line } \\
\text { workers\% }\end{array}$ & Professionals\% & $\begin{array}{l}\text { Sales } \\
\text { people\% }\end{array}$ & $\begin{array}{l}\text { First } \\
\text { line } \\
\text { supervisors\% }\end{array}$ & $\begin{array}{l}\text { Middle } \\
\text { managers\% }\end{array}$ & $\begin{array}{l}\text { Admini } \\
\text {-strative } \\
\text { employees\% }\end{array}$ & Executives\% \\
\hline Defender & $17.27(11,9.83)$ & $19.00(10,16.96)$ & $19.50(10,9.26)$ & $18.08(13,11.99)$ & $18.08(13,9.90)$ & $12.69(13,10.72)$ & $8.18(11,4.62)$ \\
\hline Analyzer & $17.50(4,9.57)$ & $41.00(4,42.03)$ & $15.00(4,4.08)$ & $15.00(4,4.08)$ & $16.25(4,4.78)$ & $10.00(4,4.08)$ & $10.00(4,4.08)$ \\
\hline Prospector & $31.31(14,18.40)$ & $13.53(12,6.96)$ & $15.77(13,8.02)$ & $13.28(14,4.61)$ & $12.21(14,4.61)$ & $9.25(13,4.60)$ & $10.46(15,5.93)$ \\
\hline Mean (\%) & $24.08^{\mathrm{a}}(29,15.88)$ & $19.85^{\mathrm{ab}(26,20.69)}$ & $17.03^{\mathrm{ab}}(27,8.06)$ & $15.51^{\mathrm{ab}}(31,9.30)$ & $15.19^{\mathrm{b}}(31,7.65)$ & $10.84^{\mathrm{ab}}(30,7.08)$ & $9.56^{\mathrm{b}}(30,5.21)$ \\
\hline
\end{tabular}

Note. Means superscripted with the same letter are not significantly different

Analysis of variance was carried out to determine if there were significant differences among the strategies in percentage of training for the job categories. The results are shown on Table 2.

Table 2

ANOVA of Percentage Training on Job Category and Strategy

\begin{tabular}{|l|c|c|c|c|l|}
\hline Source & SS & $d f$ & $M S$ & $F$ & Sig. \\
\hline Job Category & 3867.639 & 6 & 644.607 & 5.344 & 0.000 \\
\hline Strategy & 164.778 & 2 & 82.389 & 0.683 & 0.506 \\
\hline Strategy*Job Category & 4145.297 & 12 & 345.441 & 2.864 & 0.001 \\
\hline Within Groups & 22074.394 & 183 & 120.625 & & \\
\hline Total & 30743.221 & 203 & & & \\
\hline
\end{tabular}

Based on the ANOVA, (Table 2), job category was significant at $\mathrm{F}=5.344(\mathrm{p}=0.000)$ while strategy was not significant $\mathrm{F}=0.683(\mathrm{p}=0.506)$. However, the interaction between strategy and job category was significant at $\mathrm{F}=2.864(\mathrm{p}=0.001)$. These results clearly showed that within specific strategies there was discrimination of training allocation for the job categories (see Figure 1). 


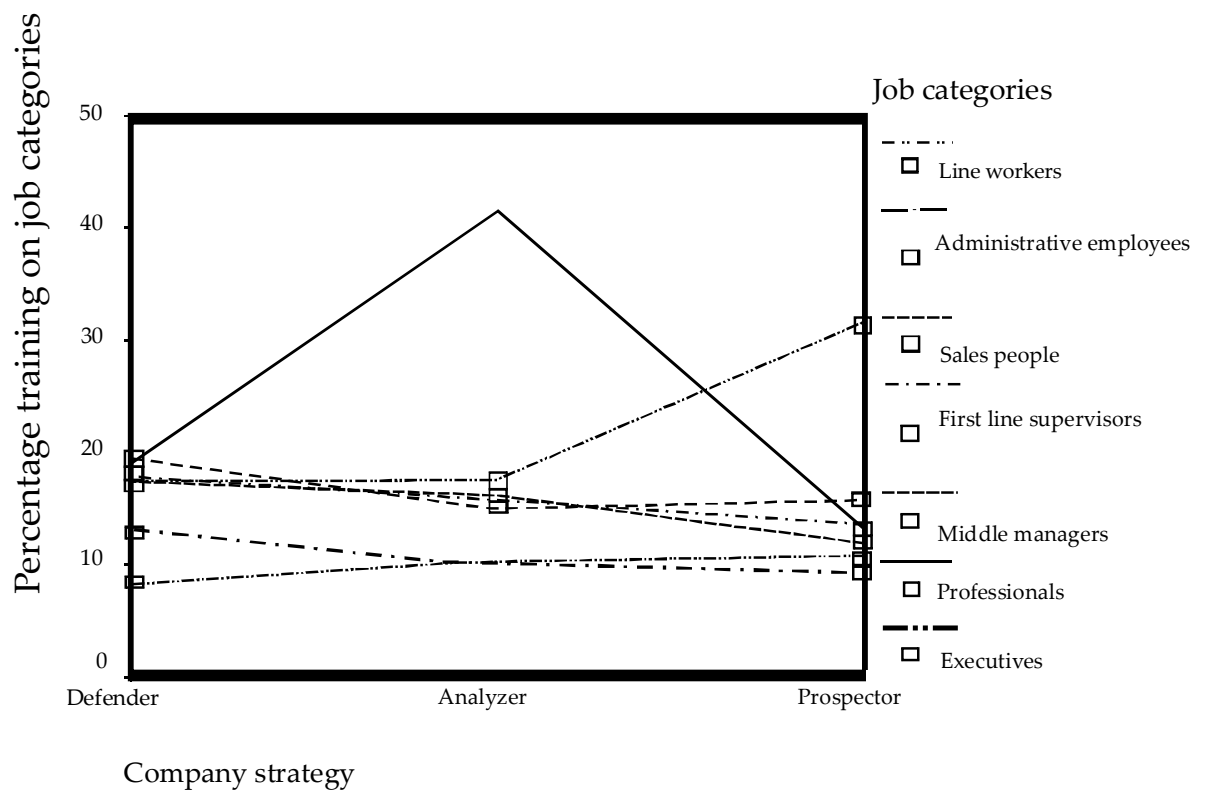

Figure 1. Estimated marginal means of \% training on job categories. 


\section{Discussion}

The findings showed that within each strategy, the emphasis of training for the different job categories varies. In this study Defenders had a higher percentage of training for sales people in comparison to Analyzers and Prospectors. Analyzers had the highest percentage of training for professionals, when compared to Defenders and Prospectors. Prospectors had the highest percentage of training for line workers in comparison to Defenders and Analyzers.

This study revealed that Prospectors emphasized training for line workers, Defenders emphasized training for sales people, and Analyzers emphasized training for professionals. The results differ from the findings of previous research (Kalata, 1999) that found that Defenders emphasized training for line workers, Analyzers emphasized training for middle managers, and Prospectors emphasized training for professionals. Schuler and Jackson (1987) found that Analyzers allocated a significantly larger percentage of training to middle managers than Prospectors. However, the finding that the Defender strategy places more emphasis on middle managers than Analyzers and Prospectors seems to be consistent with the findings of these scholars.

Analyzers monitor their competitors closely for new ideas, and adopt and imitate those that appear to be most promising (i.e. one of the characteristics of this strategy is having skills in production efficiency, process engineering and marketing). Analyzer growth is through market development (Dai, Henderson, \& Woodfine, 2002; Miles \& Snow, 1984). Dai, et. al (2002) further argue that the Analyzer's strategic response is to learn from the mistakes of others, and reproduce effective imitations at lower costs. This may explain why the Analyzers in this study would train professionals who can utilize their engineering skills, to achieve the strategic goals of the Analyzers. The goal is to engineer at lower costs than the Prospectors (Dai. et. al 2002).

According to Dai, Henderson, and Woodfine (2002), Prospectors specialize in innovative designs and materials. Prospectors also consistently experiment with new materials, and want to be the "first to market" with new products (Kalata, 1999; Miles $\&$ Snow, 1984). These characteristics of the Prospectors can explain the focus of training for line workers because they are on the shop floor; therefore, they need to have the necessary technical and procedural skills so as to control quality at the output point. This finding explains the results of research question one, where the Prospector strategy had the largest percentage of annual time allocated to job specific technical training. This finding contrasts with other findings (Kalata, 1999; Schuler \& Jackson, 1987), which indicated that, Prospectors placed greater emphasis on professionals than Defenders and Analyzers. The differences could be a result of varying business environments.

The business environment also dictates the needs of the company as it seeks to meet and satisfy customer preferences, sales priorities and production demands. Miles and Snow (1978) showed that organizations had to maintain a viable market for their goods and services, implying that there needed to be alignment between markets and products/services offered. This alignment would be reflective of the environment within which the organizations operate. If this is indeed the case, it shows that different 
companies utilizing similar strategies are aligned to meet the environmental challenges, within which they operate, hence the varying results even while strategies are similar.

Defenders had the highest percentage of training for sales people when compared with Analyzers and Prospectors. This finding is consistent with the Defender strategy that experiences growth through market penetrations (Miles \& Snow, 1984). Sales people play the role of customer assistants and provide customer service to new and existing clientele. (Dai. et. al 2002) stated Defenders do not use "complex environmental scanning processes" but the sales people understand and respond quickly to changes in customer attitudes. Dai. et. al (2002) shed light on why training the sales people is useful for the Defender strategy which has a narrow product-market that needs to be protected.

Delery (1993) indicated that differing HR practices across organizations are explained by the strategy used by the organization. This is supported by Schuler and Jackson (1988), who showed there was evidence that organizations following different strategies use different HR practices. This may explain the emphasis of different job categories by the different strategies.

\section{Recommendations}

\section{Recommendations for Chief Executive Officers (CEOs)}

Some companies within the study sample provided information indicating that they had an HR budget. However, a clear policy on the implementation plan of training was yet to be developed. Each business strategy should develop and implement a training policy that meets the strategic needs of the organization. This would ensure that a systematic process is used to link or align the training expenditure with the relevant training needs, and hopefully, this should enhance the competitive advantage of the company.

Literature shows that human resource development should strive to be a strategic unit, and the HRD strategy depends on the business strategy. This means that the HRD professionals within the organization have to think strategically, anticipate the needs of their clients, and develop ways of meeting these needs. Literature also suggests that there is a need to ensure that the corporate business strategy is understood by all relevant stakeholders and that a relevant HRD strategy is developed. Aligning the HRD strategy to the corporate strategy will ensure that the HRD professionals in the organization are involved in vital business decisions.

The study showed that KIM organizes inter-company visits for companies that participate in COYA. CEOs should consistently participate in the inter-company visits since these companies are used for benchmarking. By participating in the visits, CEOs may adopt "good business practices" as well as any HR practices that would be useful to individual companies, and are suitable for the specific strategy types. 


\section{Recommendations for HR Managers}

In this study, CEOs and HR managers stated that employee training is critical in this era, hence the allocation of training time and training budgets. Therefore, it is critical to develop an HR strategy, which offers long-term direction on planned learning and unleashes human expertise. For this reason, HR managers need to plan, design, develop, implement, and evaluate the training offered, to ensure that there is alignment between the training offered and the strategic goals of the organization. This will vary from organization to organization depending on the business strategy adopted.

Literature showed several models that can be used in order to understand the concept of strategic human resource development. The HR managers should study the different models and adopt or modify them to meet the needs of their particular company. Only models that add value to the company strategy should be adopted.

The findings of this study and literature show that organizational units/functions operate in a larger system. The success of the system depends on the interaction at the different organizational, process, and job category levels. It is important for the HR managers who are involved in planning and implementing training to consider the pros and cons for the whole organization, of particular training types for job categories. When HR managers consider the positive and negative impact of training they will be able to identify the "real gaps" and therefore, align training to the "real" organizational needs, based on the organization's strategic orientation.

\section{Recommendations for Practitioners}

The findings show that there is a lot to learn from this largely unexplored area of study. The participating companies pointed out that business theory and business practice can differ. For example, academics assume that in classroom settings individuals are taught all they need to know about running businesses; they know everything there is to know in their field of expertise. However, practitioners argue that with the advent of new technology and frequent changes, formal college training is not enough and has to be enhanced with knowledge of new trends in the industries. This means that there is a lot to learn from practice. Forums should be held by practitioners to educate the younger generation on the value of understanding how businesses using different strategies operate. This will be helpful particularly in the Kenyan context where there is the "missing middle." In this category, you find firms employing between 50-199 persons. Practitioners should share from their experiences the challenges, benefits of operating businesses, and developing a workforce. This will provide insights to those who aspire to own and run businesses in the future.

Based on the information provided by companies in the study regarding business theory and practice, it can be concluded that there is a need to reduce the gap between theory of business operations and business practice. Practitioners should invite academicians to their business premises and explain some of the differences between the theory and practice. This will provide practical examples for classroom instruction, hence enriching the experiences of academicians and students. In this way theory and practice can be used to enhance each other. 
From the results of this study, it appeared that some practitioners had successfully invested in their employees and retained them. These practitioners shared the experiences on the value of having a skilled workforce. Those with a high staff retention rate should also share their experiences, so as to demystify the fear that once an organization trains its people they will be "head-hunted" or move on to other organizations. Although these do occur, there are businesses that have retained some of their multi-skilled employees for over twenty years, Successful businesses should be studied and used as case studies in business schools. This will produce scholarship (literature) on business strategies and training, which are currently scarce in Kenya. Since this study was based on successful companies in Kenya, companies that were not part of the study sample, may wish to find out how the different strategy types link their business strategies to training, so as to remain competitive in a dynamic environment. It may be worth taking time to understand how the successful companies operate.

\section{Contribution to HRD and New Knowledge}

This study contributed towards knowledge by establishing that there are significant differences in training emphasis on job categories among business strategies in Kenya. Torraco and Swanson (1995) stated that even with technology, business success and sustaining a competitive advantage would be challenging without competent people, hence the training emphasis shown in this study. McLean and Kamau (1999) noted that HRD was underdeveloped among organizations in Kenya but this study shows that this scenario is changing and organizations are developing their human resources.

Finally, this study has shown that the Miles and Snow (1978) strategy typology exists in Kenya, as was evident from the self-reported strategies of Defender, Analyzer, and Prospector. Brewster and Pickard, 1994; Larsen, 1994; Latham, 1988 stated that there was an increased awareness on the relationships between business strategies and human resource development. The current study adds scholarship to international research on the awareness of this relationship and specifically on the relationship between business strategies and training emphasis on job categories.

Findings of this study facilitate the flow of knowledge on the differences of training emphasis among the different strategies in a developing country. Policy makers can utilize these results to encourage firms to link their business strategies to the relevant human resource practices if the firms want to remain competitive within their industry. The findings further provide information to the companies that want to understand, justify their training focus, and understand the patterns of training on different job categories. The study explains how different business strategies interact with various training types and job categories. 


\section{References}

Bowman, E. H. (1995). Next steps for corporate strategy. Advances in Strategic Management, 12, 38-68.

Brewster, C., \& Pickard, J. (1994). Evaluating expatriate training. International Studies of Management Organization, 24(3), 18-35.

Chandler, A. D. (1962). Strategy and structure. Cambridge, MA: MIT Press.

Dai, Y., Henderson, S. \& Woodline, N. (2002, June 26-28). Responsive manufacturing and the Miles and Snow strategic typology. $2^{\text {nd }}$ International Conference in Responsive Manufacturing, Giazantep,Turkey.

Delany, J. T., \& Huselid, M. A. (1996). The impact of human resource management practices on perceptions of organizational performance. Academy of Management Journal, 39, 949-946.

Delery, J. E. (1993). An inter-organizational investigation of human resource management practices: The relationship between business strategy, job and task characteristics, and human resource management practices. Unpublished doctoral dissertation, Texas A \& M University.

Drucker, P. F. (1954). The practice of management. New York: Harper \& Brothers.

Fitz-enz, J. (2000). The ROI of human capital. Measuring the economic value of employee performance. New York: AMACOM.

Gershenberg, I. (1987). The training and spread of managerial know-how, a comparative analysis of multinational and other firms in Kenya. World Development, 15(7), 931-939.

Jackson, S. E., Schuler, R. S., \& Rivero, J. C. (1989). Organizational characteristics as predictors of personnel practices. Personnel Psychology, 42, 727-786.

James, W.L., \& Hatten, K.J. (1995). Research notes and communication: Further evidence on the validity of the self-typing paragraph approach: Miles and Snow strategic archetypes in banking. Strategic Management Journal, 16(2), 161-168

Kalata, E. D. (1999). The relationship between business strategy and human resource development in Fortune 500 companies. Unpublished doctoral dissertation, University of Illinois, Urbana-Champaign. 
Kamoche, K. N. (1992). Human resources: An assessment of the Kenyan case. International Journal of Human Resource Management, 3(3), 497-521.

Larsen, H. H. (1994). Key issues in training and development. In C. Brewster \& A. Hegewisch (Eds.), Policy and practise in European human resource management: The Price Waterhouse Cranfield Survey. New York: Routledge.

Latham, G. P. (1988). Human resource training and development. In M. R. Rozenzweig \& L. W. Porter (Eds.), Annual Review of Psychology (Vol. 39, pp. 545-581). Palto Alto, CA: Annual Review Inc.

Loewenstein, M. A., \& Spletzer, J. R. (1999). General and specific training: Evidence and implications. Journal of Human Resources, 34(4), 701-734.

McLean, G. N., \& Kamau, D. (1999). Human resource development and technical education at Kenyatta University, Kenya. Paper presented at the European Conference on Educational Research, Lahti, Finland.

Miles, R. E., \& Snow, C. C. (1978). Organization strategy, structure and processes. New York: McGraw-Hill.

Miles, R. E., \& Snow, C. C. (1984). Designing strategic human resource systems. Organizational Dynamics, 13, 36-52.

Nyamberega, S. M., Sparrow, P., \& Daniels, K. (2000). The impact of cultural value orientations on individual HRD preferences in developing countries: Lessons from Kenyan organizations. International Journal of Human Resource Management, 11(4), 639663.

Pfeffer, J. (1994). Competitive advantage through people: Unleashing the power of the workforce. Boston: Harvard Business School Press.

Raghuram, S., \& Arvey, R. D. (1994). Business strategy links with staffing and training practices. Human Resource Planning, 17(3), 55-73.

Solymossy E. (2003).Looking for Miles and Snow's descriptions of business strategy prospector, analyzer, defender and reactor (LO2845) http://www.learning-org.com/ 03.01/01/01.html. Retrieved April, 6, 2004 from the World Wide Web

Schuler, R. S., \& Jackson, S. E. (1988). Linking remuneration practices to innovation as a competitive strategy. Human Resource Management Australia, 10, 6-21

Schuler, R. S., \& Jackson, S. E. (1987). Linking competitive strategies with human resource management practices. Academy of Management Executive, 1(3), 207-219. 
Shortell, S. M., \& Zajac, E. J. (1990). Perceptual and archival measures of Miles and Snow's strategic types: A comprehensive assessment of reliability and viability. Academy of Management Journal, 33(4), 817-832.

Snell, S. A., \& Dean, J. W., Jr. (1992). Integrated manufacturing and human resource management: A human capital perspective. Academy of Management Journal, 35(3), 467504.

State of Industry Report. (1998). Training and Development, 52(1), 23-43.

Sugarman, B. (2001). A learning based approach to organizational change: Some results and guidelines. Organizational Dynamics, 30(1), 62-76.

Torraco, R. J., \& Swanson, R. A. (1995). The strategic roles of human resource development. Human Resource Planning, 18 (4), 10-21.

Tung, R., \& Punnet, B. J. (1993). Research in international human resource management. In Wong-Rieger \& F. Rieger (Eds.), International management research: Looking to the future (pp. 35-53). New York: De Gruyter.

Walumbwa, F. O. (2001). Research in multinational corporation training: An integrative research review. Unpublished manuscript, University of Illinois at Urbana-Champaign.

Weinberger, L. A. (1998). Commonly held theories of human resource development. Human Resource Development International, 1, 75-93.

Youndt, M. A., Snell, S. A., Dean, J. W., Jr, \& Lepak, D. P. (1996). Human resource management, manufacturing, strategy and firm performance. Academy of Management Journal, 39(4), 836-866. 